\title{
STRATEGI PENINGKATAN KEBERDAYAAN PETANI KECIL MENUJU KETAHANAN PANGAN
}

\author{
Sitti Aminah ${ }^{1}$., Sumardjo ${ }^{2}$., Djuara Lubis ${ }^{2}$, dan Djoko Susanto \\ ${ }^{1}$ Badan Penelitian dan Pengembangan Kementerian Dalam Negeri \\ ${ }^{2}$ Fakultas Ekologi Manusia, Mayor Komunikasi Pembangunan Pertanian dan Perdesaan, IPB-Darmaga, Bogor. \\ E-mail: sittiaminah_bappedamu@yahoo.com
}

\begin{abstract}
ABSTRAK. Pembangunan pertanian belum menciptakan petani yang berdaya. Sebagian besar petani Indonesia adalah petani kecil yang pendapatan rendah, sehingga tergolong penduduk miskin. Kondisi ini menyebabkan ketidaktahanan pangan pada sebagian besar keluarga petani. Penelitian bermaksud untuk merumuskan strategi peningkatan keberdayaan petani kecil menuju ketahanan pangan. Data dikumpulkan pada Bulan Maret-Mei 2012 menggunakan metode: observasi, wawancara dan focus group discussion. Analisis data menggunakan statistik deskriptif dan structural equation modeling (SEM). Hasil penelitian menunjukan bahwa: (1) Keberdayaan petani kecil berada pada kategori rendah, dipengaruhi oleh lemahnya faktor-faktor: kualitas penyelenggaraan program, peran agen (pendamping/penyuluh/petugas), akses dan dukungan lingkungan, karakteristik petani kecil dan ketepatan proses pembelajaran. (2) Karakteristik petani dan keberdayaan petani kecil yang tergolong rendah berpengaruh terhadap rendahnya ketahanan pangan keluarga petani kecil. Strategi peningkatan keberdayaan untuk meningkatkan ketahanan pangan petani kecil melalui upaya perbaikan: kualitas penyelenggaraan program, peran pendamping, akses dan dukungan lingkungan, karakteristik petani kecil dan proses pembelajaran petani kecil.
\end{abstract}

Kata kunci: pemberdayaan, keberdayaan, petani kecil, ketahanan pangan

\section{STRATEGY EMPOWERMENT TOWARDS SMALLHOLDERS FOOD SECURITY}

ABSTRACT. Agricultural development has not created an empowered farmer. Most of the farmers in Indonesia are the peasants who have low incomes, so that they are inclue the poor. This condition causes food insecurity in most of the peasant families. The research intended to formulate strategy to increase ability of the peasants towards food security. The data were collected started on March-May 2012 using some methods: observation, interview and focus group discussion. Data has analyzed by using descriptively and structural equation modelling. The research results showed that: (1) The ability of the peasants is low, due to weak factors: quality of program implementation, the role of agents of development (facilitators/program official/extension officers), access and environment support, the peasants characteristics and The learning process of the peasants (2) The characteristics of the peasants and the peasants ability at low category affect low food security of the peasant families. (3) Strategy to improve the ability of the peasants by optimizing efforts: the implementation of the program, increasing the role and competence agents of development, increasing access and support environment, improving the characteristics of the peasatns and increasing the peasants learning process.

Key words : empowerment, ability, the peasants, food security,

\section{PENDAHULUAN}

Pembangunan pertanian belum berdampak pada peningkatan kesejahteraan petani. Sebagian besar petani adalah petani kecil yang berpendapatan rendah dan tergolong miskin. Dari total penduduk miskin sebanyak 29,89 juta jiwa (12,36 persen), sebanyak 19,93 juta jiwa berada di perdesaan dan 13,5 juta adalah petani kecil dengan kondisi kesehatan dan status gizi yang buruk, pendidikan yang rendah, besarnya jumlah tanggungan keluarga, tanah yang tidak produktif dan kecilnya pemilikan lahan (BPS 2011; Saragih 2011; Stamboel 2012). Kondisi kemiskinan menyebabkan petani kecil di negara-negara berkembang (termasuk Indonesia) menghadapi masalah ketidaktahanan pangan (FAO, 2003; Spring 2008).

Keberpihakan pemerintah terhadap petani lemah diidentifikasi dari: penurunan subsidi input, lemahnya kebijakan agraria dan proteksi pasar, penyediaan informasi dan inovasi, pengembangan sumberdaya manusia petani yang rendah dan kurangnya sarana prasarana pertanian (Wahono 2011; Machfoedz 2011). Akibatnya petani sulit mengakses input produksi, informasi dan inovasi, pasar, modal dan sarana prasarana untuk mendukung usaha tani. Kondisi memprihatinkan terjadi pada petani lahan kering. Pembangunan pertanian yang lebih fokus pada sawah irigasi (sebagian besar di Pulau Jawa) telah mengabaikan pengembangan lahan kering dan produktivitas petani menghasilkan tanaman pangan (Purwanto dkk. 2012). Di Maluku Utara, ketidakmampuan petani menghasilkan tanaman pangan menyebabkan harga pangan mahal karena ketergantungan terhadap pasokan produk pangan dari daerah lain. Data Bappenas (2011) menunjukan angka rumah tangga rawan pangan tergolong tinggi di Maluku Utara (32 persen), menduduki peringkat kedua di Indonesia.

Implementasi program pemberdayaan kerap kurang berhasil dalam membangun sumberdaya manusia petani karena faktor: partisipasi rendah, program tidak tepat sasaran karena informasi tidak akurat, intervensi pihak luar menyebabkan petani tidak terlibat dalam pengambilan keputusan, teknologi tidak sesuai kebutuhan, informasi dan inovasi 
pertanian kurang dipahami dan diterapkan oleh petani karena ketidaksesuaian gaya bahasa, saluran dan media, pihak luar sering merasa lebih tahu sehingga mengabaikan pengetahuan lokal (Ascroft \& Masilela 2004; Anyaegbunam et al. 2004). Penerapan model komunikasi linier dalam transfer teknologi ke petani melalui penyuluhan tidak mengembangkan kapasitas petani (Rhoades 1991; Lubis 2007 ; Leeuwis 2009).

Studi ini berangkat dari pemikiran bahwa petani kecil dapat diberdayakan untuk mengatasi kemiskinan bila proses pemberdayaan dilakukan dengan pendekatan dan strategi yang tepat, sehingga tujuan penelitian adalah: (1) Menganalisis tingkat keberdayaan petani kecil dan tingkat ketahanan pangan petani kecil. (2) Menganalisis faktor-faktor penentu tingkat keberdayaan petani kecil dan menganalisis pengaruh tingkat keberdayaan dan karakteristik petani kecil terhadap ketahanan pangan keluarga petani kecil (3) Merumuskan strategi untuk meningkatkan keberdayaan petani kecil menuju ke tahanan pangan.

\section{Pemberdayaan Petani Kecil}

Wolf (1985) memberikan istilah peasant untuk petani kecil yang dicirikan sebagai penduduk yang secara eksistensial terlibat dalam cocok tanam dan membuat keputusan otonom tentang proses cocok tanam. Mereka bertempat tinggal, bercocok tanam dan beternak di daerah pedesaan dan pinggiran kota, memiliki pekerjaan pokok di bidang pertanian sebagai sumber pendapatan untuk kelangsungan hidup.

Pemberdayaan memiliki artiyang beragam, studi ini mengacu pada definisi pemberdayaan menurut Ife (1995) yakni "providing people with the resource, opportunities, knowledge and skill to increase their capacity to determine their own future and participate in and affect the life of their community". Mengacu pada definisi pemberdayaan tersebut, maka hakekat pemberdayaan petani kecil adalah upaya meningkatkan kapasitas petani kecil agar mereka memiliki kemampuan, kekuatan dan akses yang lebih besar terhadap sumberdaya pembangunan guna memperbaiki dan meningkatkan kualitas kehidupannya. Petani yang berdaya memiliki pengetahuan dan ketrampilan, berperan dalam mengambil keputusan dan mampu mengelola dan mengatasi masalah usaha tani.

Pemikiran Freire (1970) tentang konsep dialog dan pendidikan orang dewasa menjadi rujukan untuk menganalisis keterlibatan petani dalam proses pemberdayaan. Ife dan Tesoriero (2008) dan Chitnis (2011) menyatakan karya kepeloporan Freire dalam program keaksaraan orang dewasa (adult literacy) Faveals and Barrios di Brazil menjadi sumber inspirasi bagi keterlibatan orang dalam proses pembangunan. Menurut Freire orang dapat bebas dari struktur penindasan jika mempunyai kesempatan berhadapan dengan masalah (problem posing) dan berpikir kritis (critical thinking). Pemberdayaan didasari oleh prinsip bahwa kearifan datang dari "bawah", Freire (1970) dengan tegas menolak alienasi penerima manfaat dalam program pemberdayaan, menurutnya "seseorang tidak utuh bila ia kehilangan kemampuan memilih, bila pilihannya adalah pilihan orang lain, dan bila keputusan-keputusannya berasal dari luar bukan merupakan keputusannya sendiri”. Oleh karenanya pemberdayaan harus memasukan strategi peningkatan kesadaran, agar orang dibantu untuk menyuarakan kebutuhan dan mengembangkan aksi untuk memenuhi kebutuhan tersebut. Servaes (2002) menyatakan dalam proses pemberdayaan perlu adanya forum dialog akar rumput (grass root dialog fora) untuk mempertemukan sumber dan agen perubahan langsung dengan warga dalam proses pengambilan keputusan, metode yang digunakan adalah penyadaran (conscientization) melalui dialog untuk mengajak warga merumuskan permasalahan sekaligus tindakan mengatasi masalah.

\section{Peran Agen Pembangunan dalam Pemberdayaan}

Menurut Leeuwis (2004) proses pemberdayaan membutuhkan peran agen pembangunan yang berperan sebagai fasilitator untuk membangun kesadaran dan penyadaran, mengeksplorasi ide, menyediakan informasi dan menyelenggarakan pelatihan. Nair dan White (2004) menyatakan peran penting fasilitator mengembangkan dialog dalam model pembaharuan budaya (Cultural Renewal Model), sebagai inisiator dan perencana yang memahami konsep manajemen, cara mengatasi masalah, bertindak sebagai pengarah orchestra dinamika kelompok dan komunikator yang mengetahui akses informasi klarifikasi, sintesis, keterhubungan dengan warga, mengembangkan diskusi dan memfasilitasi partisipasi. Ife dan Tesoriero (2008) menyatakan meskipun agen memiliki keahlian dan kearifan tertentu, namun dalam proses pemberdayaanmereka harus menghargaipenduduk lokal yang lebih memahami pengetahuan, kebudayaan, proses dan sumberdaya di lingkungan mereka. Dengan demikian, berbagi pengetahuan dan ketrampilan antara agen dengan petani sangat penting agar masing-masing pihak dapat saling belajar dan bekerjasama.

\section{Konsep Proses Pembelajaran Partisipatif}

Freire (1970) mengkritik metode pembelajaran petani yang tidak partisipatif. Menurutnya dibalik praktek penyuluhan pertanian terdapat suatu ideologi (implicit) struktur hirarkhis, vertikal, kontrol sosial dan hubungan satu arah dari para ahli kepada petani yang pada dasarnya tidak partisipatif. Tujuan pendidikan adalah "mengisi" petani dengan "pengetahuan" teknis. Freire menyebutnya "Banking Concept Education" yang menganggap pengetahuan adalah entitas yang sudah selesai dan tidak akan dipertemukan dalam dialog subjek, petani sebagai penerima pasif pengetahuan dari pihak luar. "Banking Concept Education" tidak menumbuhkan sikap kritis refleksi terhadap kebenaran pengetahuan. Freire (1970) juga menyatakan "petani yang sungguh-sungguh belajar hanyalah mereka yang menyetujui apa yang dipelajarinya dan menerapkan apa yang dipelajarinya kepada eksistensial konkret. Sebaliknya petani yang hanya diisi oleh orang dengan "isi" yang tidak disadarinya malah bertentangan dengan cara adanya, tidak dapat belajar karena mereka tidak merasa ditantang dan "digugah". Pembelajaran petani melibatkan tiga unsur yakni guru (penyuluh/petugas) dan murid (petani) sebagai subyek yang sadar (cognitive), yang diperantarai oleh obyek yang ingin diketahui dan yang dapat diketahui. Pembelajaran 
petani diawali dengan penyadaran melalui belajar mengenal masalah, menafsirkan masalah, mereflesikan dan melihat hubungan sebab akibat permasalahan dengan realitas yang dihadapi serta mengambil tindakan mengatasi masalah.

Rhoades (1990) dan Leeuwis (2009) mengajukan paradigma baru proses pembelajaran petani melalui penyuluhan dari model linier-top down ke intervensi komunikatif bercirikan komunikasi partisipatif melalui dialog. Pendekatan ini memberikan peran yang tinggi kepada petani untuk bersama-sama penyuluh dan peneliti mengidentifikasi masalah, merencanakan, melaksanakan hingga tahap mengevaluasi berbagai jenis informasi dan teknologi kepada petani.

\section{Akses dan Dukungan Lingkungan Usaha}

Menurut Lionberger dan Gwin (1982) selain komunikasi, variabel esensial untuk mendukung perubahan sosial petani yaitu ketersediaan suplai input, pemasaran, penyediaan kredit, penyediaan informasi, dan ketersedian fasilitas (pergudangan) dan infrastruktur. Sejalan dengan pendapat Lionberger dan Gwin, Mosher (1978) menyatakan bila pertanian hendak dimajukan, maka petani harus didukung dengan fasilitas jasa yang dikenal sebagai syarat pokok pembangunan pertanian, terdiri dari: pasar untuk hasil usaha, teknologi yang senantiasa berubah, tersedianya sarana produksi dan peralatan secara lokal, perangsang produksi bagi petani dan pengangkutan.

\section{Konsep Ketahanan Pangan}

FAO (1996;2010) mendefinisikan ketahanan pangan sebagai berikut "food security exist when all people at all time have physical, social, and economic access to sufficient, safe, and nutritious food which meets their dietary needs and food preferences for an active and healthy life. Niehoff (2010) menyatakan "acces" merujuk penyediaan makanan melalui produksi sendiri, membeli, pinjam, pertukaran atau hadiah. "all people" merujuk pada prinsip keadilan dan berhubungan dengan isu-isu kunci dari distribusi makanan dan hak-hak kemampuan rumah tangga mengakses makanan. "All time" merujuk pada musim dan dampak dari kondisi tekanan seperti krisis moneter. Chung et al. (1997) mengemukakan tiga pilar utama ketahanan pangan yaitu ketersediaan (availability), akses (access), dan pemanfaatan (utilization) pangan. Berdasarkan definisi ketahanan pangan oleh FAO (1996;2010), Chung (1997) dan Undang-Undang Nomor 12 Tahun 2012 tentang
Pangan, indikator ketahanan pangan keluarga petani kecil adalah: (i) ketersediaan dan kecukupan pangan untuk memenuhi kebutuhan konsumsi rumah tangga dengan mempertimbangkan musim tanam dengan musim tanam berikutnya (ii) Aksesibilitas dan keterjangkauan pangan yaitu kemampuan rumah tangga petani memperoleh pangan dengan produksi sendiri atau membeli (iii) Kualitas pangan yaitu konsumsi pangan rumah tangga petani baik berupa protein hewani dan nabati. Ketahanan pangan petani kecil dipengaruhi oleh faktor-faktor: (i) Pendapatan (Bouis and Hunt 1999 ; Rose 1999) (ii) Ukuran rumah tangga (Alderman \& Garcia, 1994 ; Rose, 1999). (iii) produksi pangan (Maxwell and Frakenberg 1992 ; FAO 2008) (iv) luas lahan garapan (Sumaryanto 2009; Stamboel 2011; Hardono, 2012), (v) Kemampuan koping strategi jangka pendek dan jangka panjang (Kirkland et al 2009; Firdaus dan Euis Sunarti 2009) dan kondisi cuaca buruk (FAO, 2008).

Berdasarkan review literatur, penyusunan kerangka penelitian untuk menganalisis faktor-faktor penentu tingkat keberdayaan petani kecil dan pengaruh tingkat keberdayaan dan karakteristik petani kecil terhadap ketahanan pangan disajikan pada Gambar 1 .

\section{METODE}

Penelitian menggunakan metode survey untuk menjelaskan kondisi (tingkat) keberdayaan dan ketahanan pangan petani kecil serta faktor-faktor yang berpengaruh terhadap keberdayaan dan ketahanan pangan petani kecil. Unit analisis dalam penelitian ini adalah kepala keluarga petani kecil di lahan kering. Lokasi penelitian adalah desa-desa penerima program smallholder livelihood (SOLID-IFAD) di Kabupaten Halmahera Barat, Provinsi Maluku Utara. Populasi penelitian berjumlah 583 kepala keluarga petani kecil yang tersebar di empat desa yaitu Tuada, Todowongi, Bukumatiti dan Taba Campaka. Responden diambil sebanyak 30 petani kecil yang memiliki lahan kurang dari 2 Hektar, sehingga total sampel untuk 4 desa sebanyak 162 orang. Pengumpulan data dilakukan pada Bulan Maret sampai Mei 2012. Data primer dikumpulkan secara langsung dari petani melalui wawancara dan penggunaan kuesioner yang memenuhi persyaratan validitas dan realibilitas. Data dari sumber lainnya (informan kunci) seperti pemimpin formal dan informal di desa dan petugas pemerintah melalui wawancara mendalam, observasi langsung dan FGD (focus group discussion) untuk memperoleh data kualitatif guna mendukung data kuantitatif.

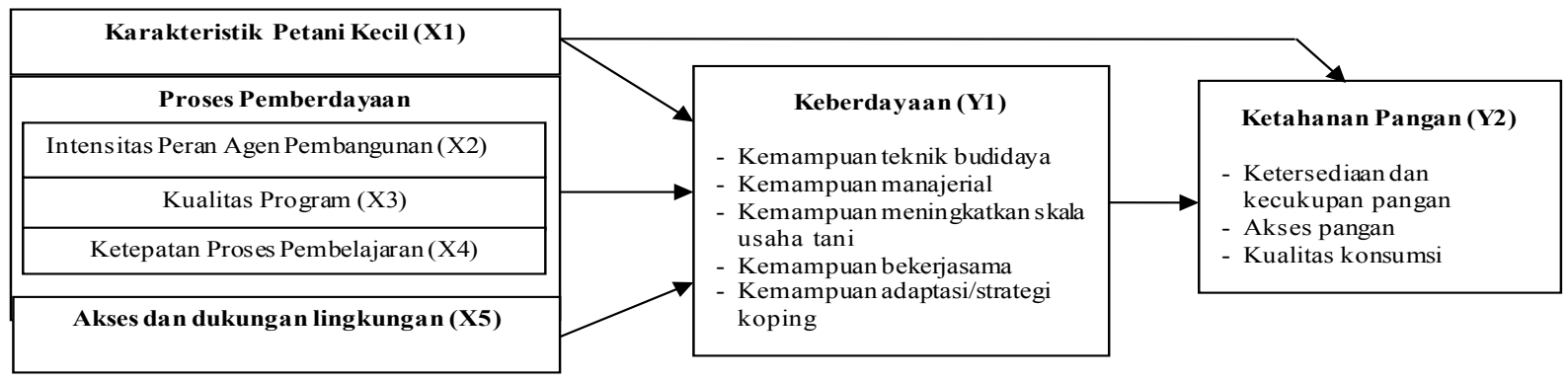

Gambar 1. Hubungan antar variabel 
Pengolahan dan analisis data menggunakan statistik deskriptif dengan program SPSS (Statistical Product and Service Solution) 16 dan statistik inferensial Structural Equation Models (SEM) dengan LISREL (Linear Structural Relationships) 8.70. Pengukuran indikator menggunakan parameter skala $1-4$, nilai maksimum (100) bila semua parameter setiap indikator bernilai 4, sehingga sebaran data merupakan skala interval dengan nilai berkisar antara 0-100. Pengelompokan kategori menggunakan empat tingkatan yaitu: nilai 0-25 kategori "sangat rendah", 26-50 kategori "rendah", dan 51-75 kategori "tinggi" dan 76-100 kategori "sangat tinggi".

\section{HASIL DAN PEMBAHASAN}

\section{Tingkat Keberdayaan dan Tingkat Ketahanan Pangan Petani kecil}

Tabel 1 Deskripsi peubah-peubah penelitian

\begin{tabular}{|c|c|c|c|}
\hline $\begin{array}{l}\text { Aspek Tingkat } \\
\text { Keberdayaan }\end{array}$ & Kelompok & $\begin{array}{c}\text { Rataan } \\
\text { total }\end{array}$ & $\begin{array}{l}\text { Hasil uji } \\
\text { beda }\end{array}$ \\
\hline $\begin{array}{l}\text { Kemampuan teknik } \\
\text { budi daya (skor) }\end{array}$ & 42,52 & 41,94 & Nyata \\
\hline $\begin{array}{l}\text { Kemampuan } \\
\text { manajerial (skor) }\end{array}$ & 45,10 & 44,56 & $\begin{array}{l}\text { Tidak } \\
\text { berbeda }\end{array}$ \\
\hline $\begin{array}{l}\text { Kemampuan } \\
\text { meningkatkan usaha }\end{array}$ & 19,81 & 22,58 & $\begin{array}{l}\text { Sangat } \\
\text { nyata }\end{array}$ \\
\hline $\begin{array}{l}\text { Kemampuan bekerja } \\
\text { sama }\end{array}$ & 28,40 & 27,97 & Nyata \\
\hline Kemampuan adaptasi & 56,53 & 57,43 & $\begin{array}{l}\text { Sangat } \\
\text { nyata }\end{array}$ \\
\hline \multicolumn{4}{|l|}{$\begin{array}{l}\text { Tingkat Ketahanan } \\
\text { Pangan }\end{array}$} \\
\hline $\begin{array}{l}\text { Ketersediaan/ } \\
\text { kecukupan pangan } \\
\text { (skor) }\end{array}$ & 42,07 & 45,58 & $\begin{array}{l}\text { Sangat } \\
\text { nyata }\end{array}$ \\
\hline Akses pangan (skor) & 41,46 & 45,26 & $\begin{array}{l}\text { Sangat } \\
\text { nyata }\end{array}$ \\
\hline $\begin{array}{l}\text { Kualits konsumsi } \\
\text { pangan (skor) }\end{array}$ & 33,73 & 34,33 & $\begin{array}{l}\text { Tidak } \\
\text { berbeda }\end{array}$ \\
\hline
\end{tabular}

Kategori: $0-<25=$ sangat rendah; $26-<50=$ rendah; $51-<75=$ tinggi; $76-100=$ sangat tinggi

Tingkat Keberdayaan Petani Kecil. Berdasarkan analisis statistik deskriptif seperti disajikan pada Tabel 1 diketahui bahwa Keberdayaan petani kecil termasuk kategori rendah pada aspek kemampuan: teknik budidaya, manajerial, pengembangan usaha, kerjasama internal dan eksternal serta adaptasi dan koping strategi. Pengetahuan dan ketrampilan petani tentang budidaya tanaman pangan tergolong rendah (skor 27.42 dan 35,19) meliputi cara pemupukan, pengendalian hama dan penyakit dan pasca panen. Penerapan inovasi teknologi baru oleh petani tergolong rendah, namun sikap petani untuk meningkatkan pengetahuan dan ketrampilan budidaya tanaman tergolong tinggi (skor 60,48). Kemampuan manajerial petani meliputi pengetahuan, sikap dan ketrampilan tergolong rendah (skor 44,69; 53,46 dan 35,93), diamati dari kemampuan yang rendah untuk: (i) merencanakan yaitu memilih komoditas, menentukan biaya produksi dan jadwal menanam dan (ii) mengevaluasi yaitu identifikasi dan mengatasi masalah serta mengambil resiko menanam komoditas baru yang lebih menguntungkan petani. Kemampuan petani meningkatkan usahatani berada pada kategori sangat rendah (rataan skor 19,81), dilihat dari tidak meningkatnya: pendapatan, simpanan modal, jangkauan pemasaran, penggunaan input dan nilai tambah hasil panen. Kemampuan petani bekerja sama antar anggota kelompok tani dan kelembagaan desa tergolong rendah (skor rataan 49,53). Kerjasama petani dengan pedagang luar desa, lembaga penyedia sarana produksi dan perbankan tergolong sangat rendah (skor rataan 7,07). Tetapi, kemampuan adaptasi atau koping strategi untuk mengatasi rendahnya pendapatan dan gangguan kekurangan pangan tergolong tinggi (skor rataan 56,53), Tingkat Ketahanan Pangan Petani Kecil. Berdasarkan analisis statistik deskriptif seperti disajikan pada Tabel 1 (Terlampir), diketahui ketahanan pangan keluarga petani kecil tergolong rendah, mencakup ketersediaan dan kecukupan pangan keluarga petani (skor 42,07).

Petani yang tidak memiliki ketersediaan beras tergolong tinggi (skor 82,72). Petani yang mengusahakan tanaman padi hanya 22 persen dari total responden dan hanya menanam sekali dalam setahun saat musim hujan (November-Januari). Padi yang dipanen hanya untuk memenuhi konsumsi rumah tangga untuk 3 sampai 4 bulan ke depan. Konsumsi beras di rumah tangga petani rata-rata satu kali dalam sehari, sehingga untuk mengatasi kekurangan beras petani mengkonsumsi umbi-umbian, sagu dan pisang. Aspek akses pangan (beras dan sumber protein) pada petani tergolong rendah (skor rataan 41,46), yaitu akses tidak langsung dengan cara membeli pangan dan bukan memproduksi sendiri. Petani fokus menanam tanaman perkebunan (terutama kelapa) sebagai sumber pendapatan utama. Ikan laut adalah sumber protein utama yang diperoleh dengan cara membeli (72 persen). Aspek berikutnya, kualitas konsumsi pangan tergolong rendah $(34,33)$. Petani mengkonsumsi sumber protein berupa ikan rata-rata 3 sampai 4 hari dalam satu minggu dan hanya mengkonsumsi telur atau tempe bila ikan mahal. Konsumsi daging sangat jarang kecuali pada saat hajatan atau perayaan agama. Kesadaran keluarga petani mengkonsumsi sayuran tergolong rendah, meskipun jenis sayuran seperti daun singkong, melinjo, daun ubi jalar serta daun dan bunga pepaya melimpah.

\section{Faktor-Faktor Penentu Keberdayaan dan Pengaruh Keberdayaan dan Karakteristik Petani Kecil Ter- hadap Ketahanan Pangan}

\section{Faktor-Faktor Penentu Keberdayaan Petani Kecil.}

Berdasarkan hasil pengujian model struktural (standardized) seperti disajikan pada Tabel 2 (Terlampir) diketahui RMSEA (Root Mean Square Residual) $=0.052$, CFI (Comparative Fit Index) $=0.92$, GFI (Goodness of Fit) $=0.95$, RFI (Relative Fit Index) $=0.90$, NFI (Normed Fit Index) $=0.91$.

Hasil analisis SEM diperoleh hasil akhir model struktural dalam bentuk diagram yang memperlihatkan faktor penentu keberdayaan dan pengaruh keberdayaan dan karakteristik petani kecil terhadap ketahanan pangan yang disajikan pada Gambar 2. faktor penentu yang mempengaruhi 
Tabel 2. Ringkasan Hasil Analisis Kelayakan Model Struktural (Pendamping Chi-Square)

\begin{tabular}{lccccccc}
\hline \multicolumn{1}{c}{ Model } & RMSEA & CFI & NFI & NNFI & RFI & IFI & GFI \\
\hline Model Struktural & 0.052 & 0.92 & 0.91 & 0.91 & 0.90 & 0.92 & 0.95 \\
$\begin{array}{l}\text { Kriteria Kelayakan } \\
\text { goodness of fit test }\end{array}$ & $<0.08$ & $\geq 0.80$ & $\geq 0.80$ & $\geq 0.80$ & $\geq 0.80$ & $\geq 0.80$ & $0.8-0.9$ \\
Evaluasi Model & Very Fit & Very Fit & Very Fit & Very Fit & Very Fit & Very Fit & Very Fit \\
\hline
\end{tabular}

Keterangan: RMSEA (Root Mean Square Residual); CFI (Comparative Fit Index); GFI (Goodness of Fit); NFI (Normed Fit Index); NNFI (Non Normed Fit Index); RFI (Relative Fit Index); IFI (Incremental Fit Index); GFI (Goodness of Fit); AGFI (Adjusted Goodness of Fit Index)

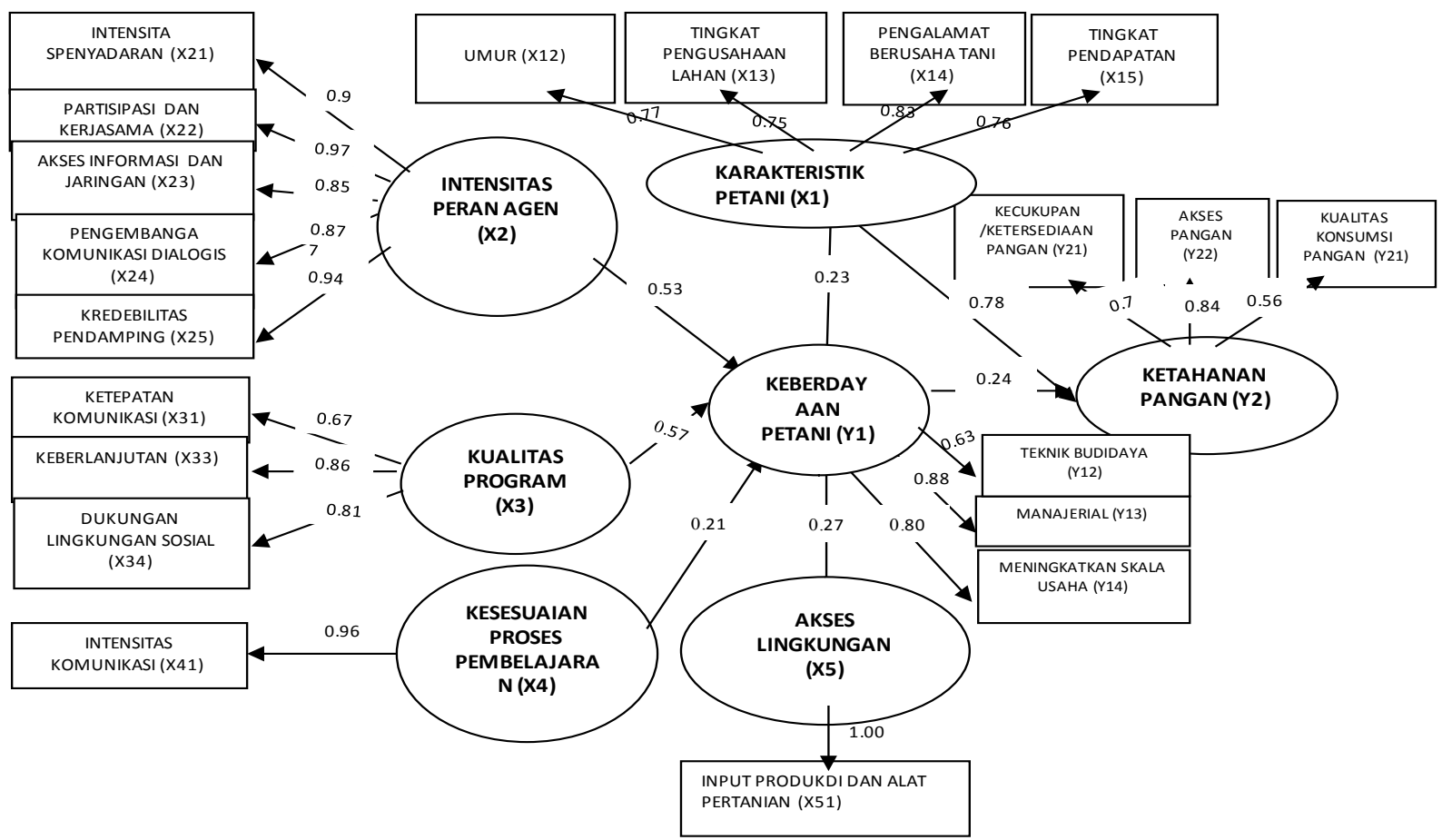

Gambar 2. Faktor Penentu Keberdayaan Petani Kecil dan Pengaruh Keberdayaan dan Karakteristik Petani Kecil Terhadap Ketahanan Pangan

keberdayaan petani berturut-turut dari yang paling besar koefisien pengaruhnya adalah: kualitas program (koefisien 0,57 ), peran agen pembangunan (koefisien 0,53), akses dan dukungan lingkungan (koefisien 0,27), karakteristik petani (koefisien 0,23) dan ketepatan proses pembelajaran (koefisien 0,21). akses dan dukungan lingkungan (koefisien 0,27), karakteristik petani (koefisien 0,23) dan ketepatan proses pembelajaran (koefisien 0,21).

Kualitas program memiliki pengaruh terkuat terhadap keberdayaan petani, dimana aspek keberlanjutan program memiliki pengaruh terbesar terhadap keberdayaan petani disusul pelibatan lingkungan sosial dan komunikasi program. Program pemberdayaan tidak berlanjut karena sering dikelola sebagai pemberian bantuan (dana, input dan alat pertanian) tanpa disertai peningkatan kapasitas dan pendampingan yang efektif. Contohnya di lokasi penelitian, program menyediakan modal kepada petani untuk usaha kegiatan bertani sayuran, beternak ayam, jual beli dan membuat kue namun tanpa disertai pendampingan dan penciptaan akses untuk pasar hasil usaha kelompok, sehingga usaha tidak berkembang dan pendapatan petani tidak meningkat. Pendampingan program bersifat temporer, jika program berakhir maka pendampingan juga berakhir, walaupun tidak terjadi perubahan positif pada perilaku petani.
Studi ini mendukung pendapat Winarto (2011) bahwa ketidakberlanjutan program sering terjadi pada program pemberdayaan petani sehingga tidak berdampak pada peningkatan perilaku petani. Faktor pelibatan lingkungan sosial (tokoh informal dan kelembagaan) tergolong rendah, padahal menurut Ife dan Tesoriero (2008) pelibatan tokoh (opinion leader) dan kelembagaan masyarakat sangat penting dalam menunjang keberhasilan program pemberdayaan. Rogers dan Shoemaker (1986) juga menyatakan tokoh desa sebagai opinion leader memiliki status sosial, kharisma serta wawasan yang dapat mempengaruhi warga berpartisipasi pada program. Aspek komunikasi program melalui sosialisasi dan ketersediaan media informasi yang rendah selain menyebabkan kurangnya pemahaman petani tentang visi, tujuan dan cara mengelola kegiatan program juga menimbulkan konflik karena kesalahan penilaian warga yang mungkin menilai program tidak adil karena mendapat informasi yang keliru.

Faktor kedua yang menentukan keberdayaan petani adalah peran agen pembangunan. Hasil analisis menunjukan intensitas peran agen tergolong rendah, pada aspek-aspek: (i) Pengembangan partisipasi menyebabkan motivasi dan keterlibatan petani rendah dalam implementasi progam. (ii) Kredibilitas agen yang rendah 
pada kemampuan teknik budidaya, kemampuan komunikasi, kedekatan serta memahami budaya komunitas menyebabkan rendahnya pembelajaran petani dan kedekatan hubungan agen-petani. (iii) Penyadaran petani yang rendah menyebabkan petani lemah dalam mengenali potensi dan peluang pengembangan sumberdaya desa, mendefinisikan masalah dan alternatif pemecahannya serta kemampuan menyuarakan kepentingan dalam forum pertemuan program (iv) Dialog sebagai sarana berbagi informasi antara petani dengan agen yang rendah menyebabkan petani sulit menghadapi dan mengatasi masalah usaha. Misalnya, kurangnya pendampingan terhadap kelompok petani yang mengelola usaha ternak ayam menyebabkan petani sulit mengatasi masalah kematian ayam massal akibat serangan hama penyakit. (v) Penyediaan akses informasi dan jaringan kerja yang rendah antara petani dengan lembaga pendukung usaha tani menyebabkan petani kesulitan memperoleh dukungan dan kerjasama dalam pengadaan input, modal, pasar dan informasi. Temuan ini sejalan dengan pendapat Nair dan White (2004), Ife dan Tesoriero (2008) dan Leeuwis (2009) yang menyatakan bahwa agen memainkan peran vital dalam mengembangkan kapasitas masyarakat melalui kerjasama dan dialog dengan petani, sehingga peran agen yang lemah berdampak pada keberdayaan yang rendah. Temuan berbeda dengan penelitian Sukesi (2009) dimana agen (Yayasan Mitra Tani Mandiri) sangat berperan dalam mengembangkan kapasitas dan kerjasama dengan petani lahan kering pada Program Agrovastoral di Nusa Tenggara Timur.

Akses dan dukungan lingkungan merupakan faktor ketiga yang menentukan keberdayaan petani kecil, terutama pada aspek ketersediaan input dan alat pertanian (koefisien pengaruh 0,27). Mayoritas petani adalah petani subsisten yang tidak memiliki sistem produksi yang stabil. Mereka bertani secara alami tanpa menggunakan pupuk dan obat pembasmi hama (pestisida) karena sulit mengakses input produksi dan alat pertanian (harga yang mahal, jarak membeli yang jauh, kelangkaan serta terbatasnya bantuan pemerintah). Akibatnya petani hanya menghasilkan sedikit tanaman pangan yang bahkan tidak mencukupi untuk memenuhi kebutuhan sendiri. Hanya sebagian kecil petani yang menggunakan pupuk dan pestisida untuk menjaga agar produksi stabil karena mengandalkan pendapatan dari budidaya tanaman holtikultura (sayuran dan kacang tanah).

Karakteristik petani merupakan faktor keempat penentu keberdayaan petani. Aspek pengalaman dan umur petani memiliki pengaruh paling dominan terhadap keberdayaan petani. Petani yang memiliki berpengalaman lebih lama dan berusia lebih tua berimplikasi pada kemampuan usaha tani (teknik budidaya, manajerial dan meningkatkan skala usaha). Aspek pendapatan berpengaruh terhadap keberdayaan petani, dimana pendapatan petani yang lebih rendah memiliki kemampuan berproduksi, manajerial dan peningkatan skala usaha yang rendah karena ketidakmampuan dalam akses informasi, modal, pasar dan input produksi pertanian. Penguasaan lahan berpengaruh terhadap keberdayaan petani, dimana petani dengan lahan yang lebih luas memiliki produksi hasil perkebunan (kelapa, cengkeh, pala, coklat) dan tanaman pangan (padi, umbi-umbian dan sayuran) yang lebih banyak sehingga berimplikasi pada tingkat pendapatan dan akses langsung terhadap pangan.

Faktor kelima penentu keberdayaan petani adalah kesesuaian proses pembelajaran petani, terutama pada aspek intensitas komunikasi. Intensitas penyebaran informasi dan pertukaran informasi tergolong rendah antara petani dengan penyuluh, pendamping, petugas, pakar, dan petani maju baik dalam kegiatan penyuluhan, pelatihan maupun pertemuan informal maupun pemanfaatan media interaktif seperti radio dan TV telah menyebabkan rendahnya kemampuan petani pada aspek manajerial, peningkatan usaha dan teknik budidaya.

\section{Pengaruh Karakteristik Petani Kecil dan Keberdayaan Terhadap Ketahanan Pangan}

Faktor karakteristik petani dan keberdayaan petani secara nyata berpengaruh terhadap ketahanan pangan. Karakteristik petani memiliki pengaruh terkuat terhadap ketahanan pangan pada aspek: pengalaman berusaha tani, umur, penguasaan lahan dan tingkat pendapatan, dengan koefisien pengaruh masing-masing $0.83,0.77,0.76$ dan 0.75. Petani yang memiliki pengalaman berusaha tani lebih lama, umur yang lebih tua dan lahan garapan yang lebih luas menghasilkan tanaman perkebunan dan tanaman pangan yang dapat dipanen antara 2 sampai 3 kali dalam setahun. Sebaliknya petani yang pengalaman usaha tani lebih singkat, berusia lebih muda, memiliki lahan yang sempit (pemberian orang tua) bahkan beberapa petani tidak memiliki lahan dan menggarap lahan milik orang tua dengan sistim bagi hasil. Sehingga, pengalaman, umur dan luas lahan garapan merupakan aspek yang menentukan ketahanan pangan di rumah tangga petani. Temuan ini sejalan dengan pendapat Maxwell and Frakenberg (1992), FAO (2008) dan Stamboel (2011) dan mendukung hasil penelitian Sumaryanto (2009) dan Hardono (2012).

Meski pendapatan perkapita keluarga petani yaitu rata-rata $\mathrm{Rp} 436.747$ per bulan, lebih tinggi dari rata-rata nasional yaitu 233.740 per kapita per bulan, namun tidak mencukupipemenuhan kebutuhan pangan dan non pangan keluarga petani dalam sebulan, karena harga pangan yang relatif mahal. Kemahalan bahan pangan di Maluku Utara karena ketidakmampuan memproduksi pangan sendiri sehingga bergantung pada pasokan (beras, daging, telur dan sayuran) dari daerah lain (wilayah Sulawesi dan Jawa). Temuan penelitian ini mendukung pendapat Bouis \& Hunt (1999) dan Rose (1999) yang menyatakan bahwa pendapatan rumah tangga yang rendah berpengaruh terhadap ketidaktahanan pangan rumah tangga karena harga pangan yang tinggi menyebabkan berkurangnya daya beli.

Keberdayaan petani dalam produksi pertanian secara nyata berpengaruh terhadap ketahanan pangan (koefisien pengaruh 0,24) pada aspek: manajerial usaha tani, meningkatkan skala usaha dan teknik budidaya masing-masing dengan koefisien 0.88, 0.80 dan 0.63 . Kemampuan manajerial yang rendah karena: (i) petani tidak merencanakan produksi yaitu 
memilih komoditas, merencanakan biaya produksi dan mengatur jadwal menanam untuk memperoleh keuntungan optimal dan (ii) petani tidak mengevaluasi usaha tani untuk mengetahui masalah dan resiko serta cara mengatasinya. Kemampuan meningkatkan skala usaha tani yang rendah diamati dari tidak terjadi peningkatan pendapatan, simpanan modal usaha, penggunaan input, nilai tambah hasil panen dan perluasan pasar. Kemampuan teknik budidaya yaitu pengetahuan dan ketrampilan yang rendah menyebabkan produksi tanaman pangan rendah yang berdampak pada ketahanan pangan yang rendah. Temuan ini mendukung penelitian Yunita (2011) dan Hardono (2012) yang menyatakan kemampuan petani yang rendah dalam produksi tanaman pangan dan meningkatkan skala usaha mempengaruhi ketahanan pangan rumah tangga petani. Menurut Ariningsih dan Rahman (dalam Niehoff, 2010) kemampuan teknik budidaya dan terbatasnya akses input produksi menjadi salah satu penyebab tingginya aktifitas menebang dan membakar hutan untuk memanfaatkan lahan subur untuk bertani.

\section{Strategi Pemberdayaan Petani Menuju Ketahanan Pangan}

Indikasi kegagalan pembangunan adalah keberdayaan petani yang rendah pada aspek kemampuan manajerial, kemampuan meningkatkan skala usaha dan teknik budidaya yang menyebabkan rendahnya produktivitas dan pendapatan petani kecil. Upaya meningkatkan keberdayaan petani membutuhkan pendekatan dan strategi pemberdayaan yang tepat pada aspek: kualitas penyelenggaraan program, peran agen pembangunan, akses dan dukungan lingkungan dan proses pembelajaran. Pertama, program pemberdayaan petani kecil hendaknya diimplementasikan secara berkelanjutan, tidak bersifat temporer (proyek) dan sekedar memberikan bantuan pinjaman modal dan alat-alat pertanian kepada petani tetapi disertai dengan pengembangan kapasitas dan pendampingan hingga tercapainya perubahan perilaku positif petani (sikap, pengetahuan dan ketrampilan). Penerapan pendekatan partisipatif dalam implementasi program menempatkan petani sebagai peserta aktif dalam pengambilan keputusan pada tahap perencanaan hingga pemanfaatan hasil. Pertemuan rapat rutin kelompok dapat dimanfaatkan sebagai media dialog yang efektif untuk berbagi pengetahuan, pengalaman, ketrampilan antara insider (petani, tokoh formal dan informal) dengan outsider (pendamping, penyelenggara program, penyuluh dan pakar). Pada saat dialog berlangsung, petani berkesempatan mengemukakan masalah, kendala dan menemukan solusi sementara outsider memperoleh informasi akurat tentang kebutuhan dan masalah yang dihadapi petani guna perbaikan kebijakan dan program. Pelibatan tokoh desa sebagai opinion leader memainkan peran penting untuk menggalang partisipasi, mediasi kepentingan dan penyelesaian konflik yang mungkin terjadi saat program berjalan.

Kedua, agen pembangunan (pendamping/ fasilitator/penyuluh) memiliki peran vital dalam pemberdayaan petani kecil di lokasi penelitian, sehingga penting untuk penyiapan agen melalui rekrutmen dengan seleksi berdasarkan kualifikasi yang ditentukan disertai pelatihan dengan penguatan materi pengembangan masyarakat. Kemampuan teknik budidaya (tanaman/ternak) dan kemampuan non teknis yaitu kemampuan membangun kesadaran, bekerja sama dan memfasilitasi sekaligus membangun dialog sebagai sarana berbagi pengetahuan dan ketrampilan dengan petani merupakan jaminan sukses keberhasilan program pemberdayaan.

Ketiga, dukungan input produksi dan alat pertanian berperan penting dalam meningkatkan produksi pertanian dan tanaman pangan. Kemahalan harga pupuk dan obatobatan memerlukan intervensi kebijakan pemerintah untuk mempertimbangkan pemberian subsidi pupuk dan obat pembasmi hama kepada petani dan mengaktifkan kembali koperasi pertanian agar petani mudah mengakses sarana produksi, kredit modal dan pasar. Sejalan dengan itu, perlu penyiapan petani untuk mengembangkan teknik pertanian berkelanjutan dengan memanfaatkan sumberdaya lokal dalam penyediaan benih, pupuk hijau dan pengendalian hama terpadu. Penerapan teknik pertanian "Low External Input Sustainable Agriculture" (LEISA) berkombinasi dengan "pengembangan Teknologi Partisipatif" untuk menggabungkan ilmu pengetahuan dari luar dengan pengetahuan petani lokal dengan harapan terjadi peningkatan produksi secara stabil dan berkelanjutan.

Keempat, Diperlukan perubahan pola komunikasi dalam pembelajaran petani yang bersifat satu arah ke komunikasi dialogis. Komunikasi dialogis memberikan peluang terjadinya pertukaran informasi antara pengetahuan lokal petani dengan teknik bertani yang dibawa oleh penyuluh, peneliti/pakar, maupun antar petani. Pengembangan komunikasi dialogis dalam pembelajaran petani melalui: (i) Keikutsertaan dan keterlibatan petani bersama-sama penyuluh dan peneliti dalam mendefinisikan masalah dan menganalisis kebutuhan sebagai dasar penyusunan agenda penyuluhan dan penelitian, mencari solusi bersama, adaptasi teknologi sederhana dan praktek bertani hingga mengevaluasi adapatasi teknologi dan praktek bertani (ii) Pemanfaatan kelompok tani sebagai media bagi petani untuk saling berinteraksi dan berbagi informasi dalam mengidentifikasi isu-isu, masalah serta mengemukakan solusi bersama yang difasilitasi oleh penyuluh atau fasilitator di desa. (iii) Meningkatkan intensitas pertemuan petani dengan kelompok tani maju yang berhasil dalam pengembangan komoditas tertentu dari aspek teknik budidaya, pengelolaan hingga pemasaran. (iv) Meningkatkan intensitas kesempatan petani belajar dari pengalaman sendiri melalui sekolah lapang, belajar melalui demplot percontohan budidaya tanaman/ternak dan berkunjung (benchmarking) ke daerah lain yang lebih berhasil.

\section{SIMPULAN}

Keberdayaan petani kecil lahan kering tergolong rendah pada aspek kemampuan mengelola usahatani, meningkatkan skala usaha dan teknik budidaya. Faktor-faktor penentu yang berpengaruh secara 
nyata adalah: (i) Kualitas penyelenggaraan program yang rendah, (ii) peran pendamping yang lemah (iii) akses dan dukungan lingkungan yang rendah (iv) karakteristik petani dan(v) proses pembelajaran petani yang kurang tepat. Ketahanan pangan keluarga petani kecil termasuk kategori rendah dalam menyediakan dan memenuhi kebutuhan pangan, mengakses dan mengkonsumsi pangan. Ketahanan pangan secara nyata dipengaruhi oleh: (i) rendahnya keberdayaan petani pada aspek kemampuan pengelolaan usaha tani dan teknik budidaya yang mendorong pendapatan petani dan (ii) rendahnya faktor-faktor internal yakni pengalaman berusaha tani, umur, tingkat pendapatan dan tingkat pengusahaan lahan. Strategi peningkatan keberdayaan petani menuju ketahanan pangan dengan memperbaiki faktor: kualitas penyelenggaraan program, peran agen pembangunan, akses dan dukungan lingkungan, proses pembelajaran dan karakteristik petani.

\section{DAFTAR PUSTAKA}

Anyaegbunam C, Mefalopulos P, and Moetsabi T. 2004. Participatory rural communication appraisal: starting with the People. FAO of The United Nation-Rome.

Alderman H., and Garcia M. 1994. Food security and health security: explaining the levels of nutritional status in Pakistan. Economic Development and Cultural Change. 42 (3).

Ascroft, J and Masilela, S. 2004. Participatory decission making in third world development. in Sherly White \& Sadanandan Nair, Participatory communication: working for change and development (pp.259-294) New Delhi: Sage Publications.

Bappenas. 2011. Laporan Millenium Development Goals. Jakarta: Bappenas.

Bouis H, Hunt J. 1999. Linking food and nutrition security: past lesson and future opportunities. Asian Development Review 17 (12).

BPS. 2011. Perkembangan Kemiskinan.(http://www. bps.go.id)

Chung, K. L. Haddad, J. and Ramakhrisna, F.R. 1997. Identifying the food insecure. The application of mixed-method approach in India. Washington, DC: International Food Policy Research Institute.

Chitnis, K. 2011. Recasting the process of participatory communication through Freirean praxis: the case of the comprehensive rural health project in Jamkhed, India. Paper presented at the annual meeting of the International Communication Association, Sheraton New York, New York City, NY. September, 28.
Freire, P. 1970. Pedagogy of the oppressed. New York, NY: Continuum.

FAO. 1996. Assessment of the food security situation. Roma: Committee on World Food Security.

FAO. 2008. The state of food insecurity in the world. High food prices and food security-threath and opportunities. Rome: Food Agricultural and Organization of the United Nation.

Hardono, S.G. Analisis Ketahanan Pangan Rumah Tangga Petani di Beberapa Propinsi. Disertasi. Bogor: IPB.

Ife, J. 1995. Community Development: Creating Community Alternatives - Vision, Anallysis and Practice: Australia: Longman Australia Pty. Ltd.

Ife, J and Tesoriero. 2008. Community development. Alternatif pengembangan masyarakat di era globalisasi (Terj.). Yogyakarta: Pustaka Pelajar.

Leeuwis, C. \& Anne, V.D.B. 2004. Communication for Rural Innovation. Rethinking Agricultural Extension. Blackwell Science.

Leeuwis, C dan Anne, V.D.B. 2009. Komunikasi untuk inovasi pedesaan (Terj.). Berpikir kembali tentang penyuluhan pertanian. Jakarta: Kanisius.

Lubis, D. 2007. Komunikasi Menuju Komunitas Pembelajar. Dalam Ekologi Manusia (pp. 317326. Bogor: IPB Press. .

Lionberger, H. F and Gwin, P.H. 1982. Communication strategis : A guide for agricultural change agent. The Interstate Printers and Publisher, Inc. Denville Illionis.

Maxwell, S and Frankenberger, T.R. 1992. Household Food Security: Concepts, Indicators, Measurement. A Technical Review. New York: Jointly Sponsored by United Nations Children's Fund and International Fund for Agricultural Development.

Machfoedz, M.M. 2011. Pedesaan Sebagai Sumber Pangan. dalam Ekonomi politik pangan. (pp. 83114). Jakarta: Comedia Publisher.

Mosher, AT. 1978. Thinking About Rural Development. New York: The Agricultural Development Council. Inc.

Niehof, A. 2010. Food diversity, vulnerability and social change. Research finding from insular Southeast Asia.Wageningen Academic Publishers.

Purwanto, R. Sulaeman, A. dan Watimena, G.A. 2012. Sejarah dan Perkembangan Revolusi Hijau, Revolusi Bioteknologi dan Revolusi Hijau Lestari. dalam Merevolusi revolusi hijau: Pemikiran Guru Besar IPB. (pp. 3-18). Bogor: IPB Press.

Rose D. 1999. Economic determinants and dietary consequences of food insecurity in The United States. Community and International Nutrition. American Society for Nutritional Sciences. 
Rhoades, R.E. 1990. Models, means, and methods: Rethinking rural development research in Asian training of trainers on farm-farm diagnostic skills. Diedit oleh R. E. Rhoades, V. N. Sandosal, dan C. P. Bayalanon. Los Banos: University of Phillipines, Los Banos, The Phillipines.

Rogers, Everett M. and Shomaker, F. Floyd. 1986. Communication of innovation: A cross cultural approach. London: Collier Mac Millan Publisher.

Servaes J. 2002. Communication for Development: one World, Multiple Cultures. Second Printing. Hampton Press, Inc. New Jersey: Cresskill.

Stamboel, K.A. 2012. Panggilan keberpihakan: Strategi mengakhiri kemiskinan di Indonesia. Jakarta: Gramedia Pustaka Utama.

Wahono, F. 2011. Kedaulatan pangan: Agri-culture bukan agri-business mensiasati negara lupa bangsa. dalam Ekonomi politik pangan. (pp.1933). Jakarta: Comedia Publisher.

Kirkland T, Kemp R, Hunter, L.M, and Twine W. 2009. Toward Improve Understanding of Food Security: A Methodological Examination Based in Rural South Africa. Submited For ASA Presentation Consideration.
Kirkland,T., Kemp, R., Hunter L.M., and Twine W. 2009. Toward improve understanding of food security: A methodological examination based in rural South Africa. Submiited fo ASA Presentation Consideration. January

Sunarti, E., Firdaus. 2009. Hubungan antara tekanan ekonomi dan mekanisme koping dengan kesejahteraan keluarga wanita pemetik teh. Jurnal Keluarga dan Konsumen. 2(1) 21-31

Sumaryanto. 2009. Diversifikasi Sebagai Salah Satu Pilar Ketahanan Pangan. Forum Agro Ekonomi, 27 (2): 93-108

Spring, O.U. 2008. Facing global environment change: climate change, food sovereignty and security in the anthropocene co-sponsorship proposed. Paper presented at the 50th ISA annual convention, New York. February 15-18.

Yunita. 2011. Strategi peningkatan kapasitas petani padi sawah lebak menuju ketahanan pangan rumah tangga di Kabupaten Ogan Ilir dan Ogan Komering Ilir. Provinsi Sumsel. Disertasi. IPB Bogor 